\title{
Przestrzenne zmienności parametrów odkształceniowych gruntów organicznych
}

\author{
Spatial variability of deformation parameters of organic soils
}

\author{
Simon Rabarijoely \\ Katedra Geoinżynierii, Szkoła Główna Gospodarstwa Wiejskiego w Warszawie; simon_rabarijoely@sggw.pl
}

\begin{abstract}
Zarys treści: Niniejszy artykuł porusza problem doboru parametrów geotechnicznych w projektowaniu inżynierskim. Przedstawione zostały metody statystyczne mające na celu oszacowanie parametru charakterystycznego. Przegląd stanu wiedzy zawiera opis parametrów geotechnicznych wykorzystanych do analizy statystycznej. Dodatkowo przedstawione zostały badania polowe (CPT i DMT) wykonane na zaporze czołowej w Nieliszu wraz z interpretacją uzyskanych wyników oraz zależnościami empirycznymi służącymi do określenia wartości analizowanych parametrów. W podsumowaniu artykułu zaproponowano także dobór parametrów z wykorzystaniem klasycznej metody statystycznej oraz metody geostatystycznej krigingu zwyczajnego.
\end{abstract}

Słowa kluczowe: CPT, DMT, parametry geotechniczne, analiza statystyczna, geostatystyka, kriging

Abstract: This paper presents the problem of parameter selection in geotechnical engineering design. The statistical methods with literature review to estimate the characteristic parameter value was described. The literature review includes the description of the geotechnical parameters using for statistical analysis. In addition, the field tests (CPT and DMT) are presented together with the interpretation of the obtained results. The empirical relationships serving to calculate the parameter values was analyzed. Then Nielisz embankment was characterized, where the object for which studies were performed the CPT and DMT tests. Finally, the selected parameters using the statistical method of classical and geostatistical methods of ordinary kriging was carried out.

Keywords: CPT, DMT, geotechnical parameters, statistical analysis, geostatistics, kriging

\section{Wstęp}

Podstawowym dokumentem regulującym zasady projektowania budowli geotechnicznych w krajach Unii Europejskiej jest Eurokod 7. Według tego dokumentu jednym $z$ najważniejszych zadań $w$ projektowaniu inżynierskim jest dobór parametrów, na podstawie których określa się stany graniczne. W artykule przedstawione zostały parametry geotechniczne, które będą wykorzystywane do późniejszej analizy statystycznej. Opisana została także metodyka sondowań CPT oraz badań dylatometrycznych DMT wraz z interpretacją wyników pomiarowych. W celu prawidłowego doboru parametru charakterystycznego Eurokod 7 zaleca jego ostrożne oszacowanie za pomocą metod statystycznych. W artykule przedstawiono zastosowanie dwóch metod statystycznych mających na celu dobór wybranych parametrów geotechnicznych a także wyniki analiz pokazujące zakres zmienności danego parametru dla konkretnego obiektu. Uzyskane parametry poddano analizie statystycznej $z$ wykorzystaniem metody klasycznej oraz metody geostatystycznej - interpolacji krigingu. W podsumowaniu artykułu przedstawiono porównanie i interpretację wyników uzyskanych z analiz.

\section{Postawy teoretyczne (CPT/DMT)}

Pierwsze sondowania statyczne rozpoczęto już w roku 1932. Sondy miały o wiele prostszą budowę niż te we współczesnych czasach. Wyposażone były w końcówkę stożkową oraz zegar, który pokazywał wartość przyłożonego obciążenia (Meigh 1987). Do- 
Tabela 1. Zależności empiryczne służące do wyznaczania parametrów geotechnicznych z wyników badań CPT oraz DMT Table 1. Empirical relationships for determining the geotechnical parameters of the test results CPT and DMT

\begin{tabular}{|c|c|c|c|c|}
\hline $\begin{array}{c}\text { Parametr geotech- } \\
\text { niczny } \\
\text { Geotechnical parameters }\end{array}$ & $\begin{array}{l}\text { (CPT) } \\
\text { Równanie } \\
\text { Equation }\end{array}$ & $\begin{array}{l}\text { Autor } \\
\text { Author }\end{array}$ & $\begin{array}{l}\text { (DMT) } \\
\text { Równanie } \\
\text { Equation }\end{array}$ & $\begin{array}{l}\text { Autor } \\
\text { Author }\end{array}$ \\
\hline Moduł ściśliwości M & $\mathrm{M}=\alpha \cdot\left(\mathrm{q}_{\mathrm{t}}-\sigma_{\mathrm{vo}}\right)$ & Senneset i in. (1989) & $\begin{array}{c}(2) \\
\mathrm{I}_{\mathrm{D}} 0.6 \\
\mathrm{R}_{\mathrm{M}}=0.14+2.36 \cdot \log \mathrm{K}_{\mathrm{D}} \\
0.6<\mathrm{I}_{\mathrm{D}}<3.0 \\
\mathrm{R}_{\mathrm{M}}=\mathrm{R}_{\mathrm{MO}}+\left(2.5-\mathrm{R}_{\mathrm{MO}}\right) \cdot \log \mathrm{K}_{\mathrm{D}} \\
\mathrm{R}_{\mathrm{MO}}=0.16+0.36\left(\mathrm{I}_{\mathrm{D}}-0.6\right) / 2.4 \\
\mathrm{I}_{\mathrm{D}} 3.0 \\
\mathrm{R}_{\mathrm{M}}=0.5+2 \cdot \log \mathrm{K}_{\mathrm{D}} \\
\mathrm{K}_{\mathrm{D}}>10 \\
\mathrm{R}_{\mathrm{M}}=0.32+2.18 \log \mathrm{K}_{\mathrm{D}} \\
\mathrm{R}_{\mathrm{M}}=0.85 \mathrm{R}_{\mathrm{M}}<0.85\end{array}$ & Marchetti (1980) \\
\hline
\end{tabular}

datkowo sonda była wciskana za pomocą siły ludzkiej. Przez lata sonda statyczna CPT uległa znacznej zmianie, zarówno pod względem budowy jak i możliwości wykonywania różnych pomiarów geotechnicznych. Aktualnie sonda CPT oraz CPTu często jest wykorzystywana $\mathrm{w}$ polowych badaniach podłoża gruntowego. Popularność tych urządzeń wynika z łatwości, szybkości, dokładności i powtarzalności wykonywanych badań (Lunne i in. 1997, Młynarek i in. 2003).

Pierwsza publikacja na temat metodyki badań dylatometrycznych DMT została opracowana przez Marchettiego (1980). Twórca dylatometru opisuje w tym artykule jak za pomocą tego urządzenia określić odkształceniowe parametry geotechniczne. Dzięki mało skomplikowanym pomiarom z czasem rosło zainteresowanie badaniami dylatometrycznymi. Przeprowadzano coraz więcej doświadczeń, co wpłynęło na rozwój sprzętu oraz na sprecyzowanie interpretacji wyników badań. Na podstawie otrzymanych wyników badań wyznaczono moduł ściśliwości gruntów. Wartość parametru została wyznaczone na podstawie zależności opisanych w literaturze (Tabela 1). W celu wyznaczenia modułu ściśliwości z sondowań CPT zastosowano zależności wymienione $\mathrm{w}$ tabeli 1. Do określenia wartości modułu ściśliwości użyto równania 1 (Senneset i in. 1989). Dla współczynnika zależnego od rodzaju gruntu - $\alpha$ przyjęto wartość 3 właściwą dla gruntów organicznych. W przypadku analizy wyników pomiarowych $z$ badań DMT również skorzystano z zależności empirycznych (Tabela 1). Dla ustalenia wartości modułu ściśliwości posłużono się wzorami Marchettiego (1980). Wielkość parametru uzależniona jest $\mathrm{w}$ tym przypadku od wskaźnika materiałowego $\mathrm{I}_{\mathrm{D}}$ oraz wskaźnika parcia bocznego $\mathrm{K}_{\mathrm{D}}$.

W celu przeprowadzeniu analizy statystycznej, dla wyników uzyskanych $\mathrm{z}$ sondowania CPT oraz DMT wykorzystano program BAYANAL. Pozwala on na oszacowanie parametrów dla podejścia Bayesa oraz dla podejścia klasycznego. W artykule opisane zostało jedynie wnioskowanie klasyczne oraz podejście Bayesa (Rabarijoely i in. 2012, 2013). W raporcie wygenerowanym przez program BAYANAL otrzymujemy wartość średnią oraz odchylenie standardowe badanego parametru. W podejściu klasycznym wielkość odchylenia oraz średniej oblicza się według znanych wzorów.

\section{Metoda geostatystyczna - proces interpolacji metodą krigingu}

Geostatystyka jest metodą matematyczną polegającą na opisie zmiennej zregionalizowanej. W latach 1962-1963 powstał pierwszy obszerny artykuł opisujący podstawy geostatystyki. Autorem tej rozprawy był George Matheron, który uważany jest za twórcę tej metody. W kolejnych latach powstawało wiele prac naukowych, które wpłynęły na rozwój geostatystyki. Dzięki temu ma ona dziś zastosowanie w dziedzinach nauki takich jak hydrologia, geologia, meteorologia czy geotechnika.Spośród różnych metod estymacji wykorzystywanych $\mathrm{w}$ geostatystyce, szczególne znaczenie dla nauki o gruncie ma interpolacja krigingu zwyczajnego. Pozwala ona na wykreślenie mapy izolinii, która przedstawia zmienność parametru geotechnicznego na badanym obszarze. W krigingu zwyczajnym, wartość interpolowana ma postać średniej ważonej, zaś informacje dotyczące zmienności badanego parametru dostarcza semiwariogram (Kokesz 2010). Zależność przestrzenna (autokorelacja) istnieje wtedy, gdy badane zjawiska $\mathrm{w}$ jednej przestrzeni zwiększają lub zmniejszają prawdopodobieństwo wystąpienia danego zjawiska W przestrzeni sąsiadującej. Model wariogramu stanowi charakterystykę ciągłości przestrzennej występującą w badanym zbiorze danych (Zawadzki 2011). Określa on zależność między średnią zróżnicowaną wartością M oraz odległością między miejscami pomiaru (Marmol 2002). 
Do konstrukcji izolinii modułu ściśliwości M wykorzystano metodę krigingu. Metoda ta składa się $z$ dwóch etapów. Pierwszy etap polega na określeniu przestrzennej korelacji opisywanego zjawiska. Do opisania takiej korelacji stosuje się najczęściej wariogram lub kowariancję (Cressie 1991).W drugim etapie na podstawie danych pomiarowych i wariogramu wykonywana jest interpolacja. Dokładność wariogramu silnie determinuje dokładność interpolacji. Ogólne równanie wariogramu eksperymentalnego ma postać:

$$
\gamma_{h}=\frac{1}{2 N_{h}} \sum_{i=1}^{N_{h}}\left(P_{x}-P_{i}\right)^{2}
$$

gdzie:

$\gamma(h)$ - wartość wariogramu dla dystansu $h$,

$N_{h}$ - liczba par punktów dla dystansu $h$,

$P_{x}-$ wielkość obserwowana w punkcie $x$,

$P_{i}$ - wielkość obserwowana w punkcie $i$.

Wyznaczenie wartości wariogramu dla określonych odległości ( $1 \mathrm{hm}, 2 \mathrm{hm}$ itd.) nie jest możliwe ze względu na nieregularne rozmieszczenie punktów pomiarowych.W tym celu definiuje się tolerancję odległości, którą zwykle przyjmuje się jako połowę kroku pomiędzy kolejnymi punktami pomiarowymi. Wartość wariogramu dla dystansu $2 h$ obliczana jest ze wzoru (1), w którym uwzględnia się wszystkie punkty z zakresu $2 h \pm$ tolerancja.Przebieg wariogramu eksperymentalnego wyznaczają punkty obliczone dla poszczególnych odległości. Ze względu na niejednorodność zmienności procesów środowiskowych względem kierunków świata wariogramy empiryczne, oprócz odległości, są także funkcją kierunku.Wyznaczenie punktów wariogramu eksperymentalnego umożliwia znalezienie równania matematycznego opisującego jego przebieg. Tworzony jest wariogram

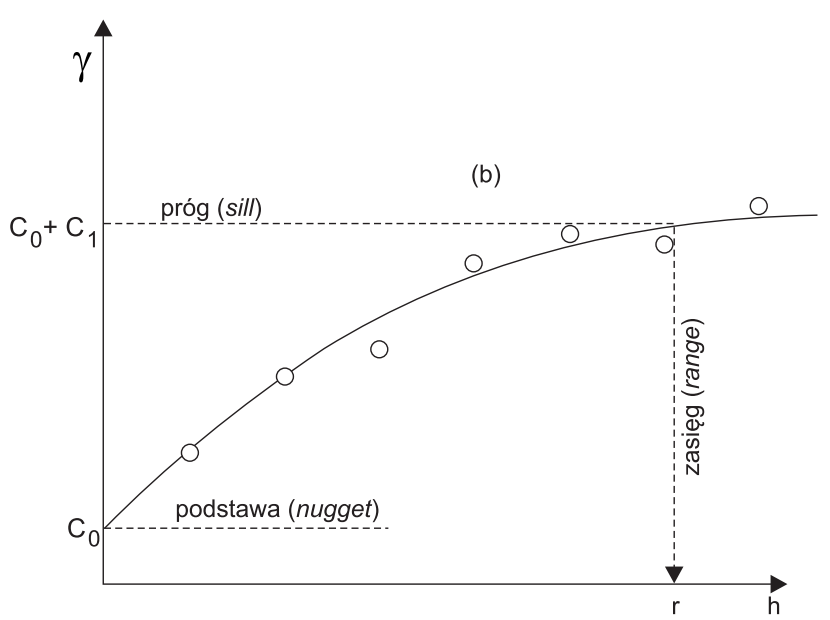

Ryc. 1. Wykres zależności semiwariancji od odległości między punktami pomiarowymi $h$

Fig. 1. Semivariance graph of the distance between the measuring points $h$ teoretyczny (ryc. 1), do którego opisu wykorzystywane są następujące parametry:

- zasięg oddziaływania - odległość powyżej której wartość wariogramu jest quasi-stała,

- wartość progowa (próg) - wartość wariogramu odpowiadająca zasięgowi oddziaływania,

- podstawa - wartość wariogramu dla dystansu zbliżonego do zera, nazywana także ,efektem samorodków".

\section{Opis obiektu i charakterystyki zapory czołowej zbiornika wodnego w Nieliszu}

Zbiornik wodny Nielisz usytuowany jest $\mathrm{w}$ dolinach rzek Wieprz i Por. Położony jest w południowo zachodniej części województwa Lubelskiego. Zbiornik ten zlokalizowany jest na terenie kilku wsi należących do powiatu zamojskiego, są to: Nielisz, Nawóz, Deszków i Kulików.

Zbiornik Nielisz ze względu na położenie względem rzek został podzielony na dwie części. Jedna część leży w dolinie rzeki Wieprz, druga zaś w dolinie rzeki Por. Łączna powierzchnia zbiornika to $9,5 \mathrm{~km}^{2}$, a całkowita pojemność to $19,5 \mathrm{mln} \mathrm{m}^{3}$. Szczególowe parametry zbiornika w Nieliszu można znaleźć $w$ wielu publikacjach np. Spółka Wodno - Ściekowa Wieprz 1991, Geoproblem 1992, Bipromel 1994 i 1997, Geoteko 1992, 1994 i 1995, Katedra Geotechniki 1989, Bortkiewicz, Szmagaj 1996. Ważniejsze z parametrów to:

- Normalny poziom piętrzenia NPP=197,50 m n.p.m.

- Maksymalny poziom piętrzenia max PP $=198,50$ m n.p.m.

- Minimalny poziom piętrzenia min PP $=195,00$ m n.p.m.

- Powierzchnia zalewu przy NPP $F_{c}=888$ ha

- Powierzchnia zalewu przy min PP $\mathrm{F}_{\mathrm{m}}=377$ ha.

Główną budowlą hydrotechniczną położoną na tym obiekcie jest zapora czołowa (ryc. 2). Dodatkowo w celu okresowego piętrzenia wody wybudowany został również jaz oraz grobla. Jaz umiejscowiony jest w okolicach prawego przyczółka (ryc. 2). Zapora czołowa zbudowana została na terenie wsi Nielisz. Łączna długość zapory czołowej wynosi $845 \mathrm{~m}$ a jej maksymalna wysokość $6,5 \mathrm{~m}$. Wysokość piętrzenia dla zapory czołowej to 8,58 m (Spółka Wodno - Ściekowa Wieprz 1991, Geoproblem 1992, Bipromel 1994i 1997, Geoteko 1992, 1994 i 1995, Katedra Geotechniki 1989, Bortkiewicz i Szmagaj 1996).

Podłoże gruntowe zbiornika stanowią holoceńskie terasy zalewowe. Od teras wysokich separuje je krawędź o dużym spadku. Wysokość bezwzględna terasy zalewowej waha się od $191 \mathrm{~m}$ n.p.m. do nawet 225,00 m n.p.m. Wysokości bezwzględne wybranych form rzeźby w rejonie zbiornika wynoszą: 


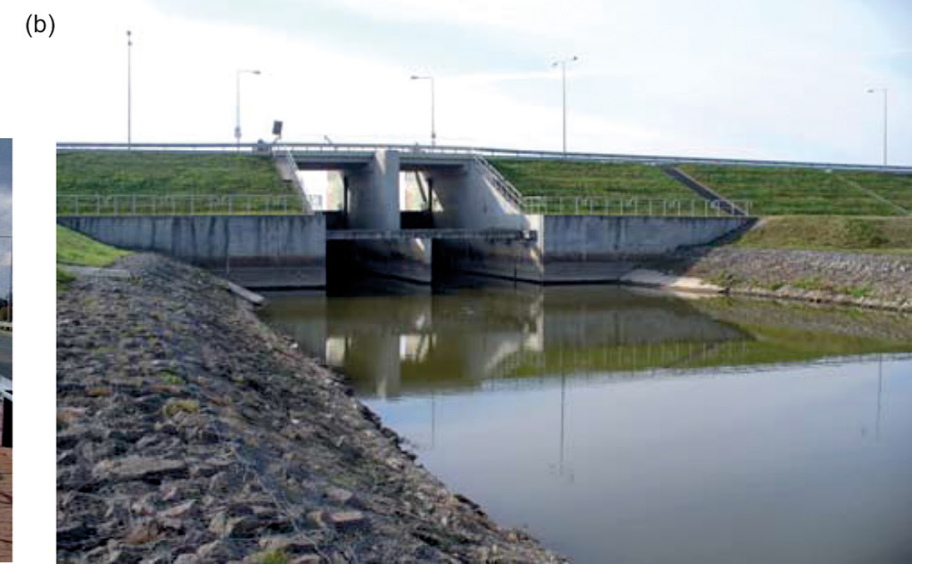

(a)

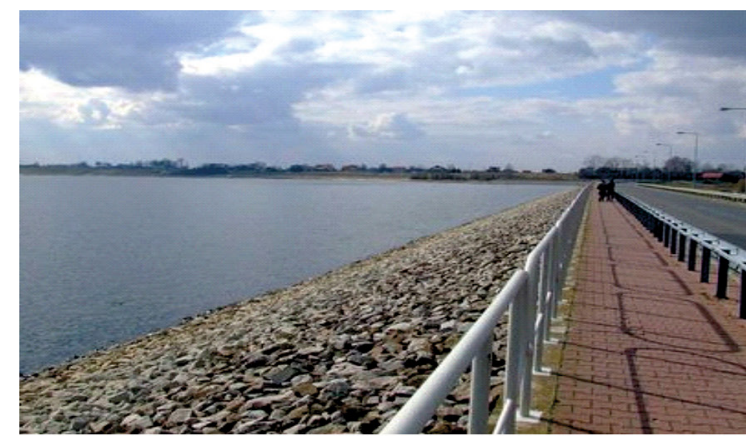

(b)

Ryc. 2. (a) Zapora czołowa w Nieliszu. (b) Jaz zapory czołowej zbiornika głównego

Fig. 2. (a) Nielisz dam. (b) Front of the main reservoir of Nielisz dam

- terasy zalewowy rzeki Wieprz 191,00-207,00 m n.p.m.

- terasy zalewowy rzeki Por 195,00-204,00 m n.p.m.

- terasy wysoki - maksymalna wysokość 225,00 m n.p.m.

\section{Charakterystyka warunków geotechnicznych}

Podstawowym dokumentem określającym warunki posadowienia oraz ich przynależność do kategorii geotechnicznej określa Eurokod 7, a mianowicie norma EN 1997-1:2008. Bazując na podziale wyznaczonym przez Eurokod 7 zaporę czołową w Nieliszu można przydzielić do 3 kategorii geotechnicznej zagrożenia bezpieczeństwa (Garbulewski i in. 2007, Rabarijoely 2012, Rabarijoely i in. 2013). Wpływ na to ma występowanie gruntów słabonośnych, skomplikowane warunki posadowienia oraz obciążenia danej konstrukcji. Na terenie posadowienia zapory czołowej występują grunty organiczne oraz spoiste $\mathrm{w}$ stanie miękkoplastycznym. Litologia oraz miąższość warstw jest bardzo zróżnicowana. Miąższość utworów holoceńskich tarasu wynosi od 3 do $5 \mathrm{~m}$. Składają się one głównie z pyłów, pyłów piaszczystych, gruntów organicznych oraz piasków pylastych. Poniżej utworów holoceńskich znajduje się trzymetrowa warstwa utworów plejstoceńskich, w skład których wchodzą między innymi glina pylasta, pył i pył piaszczysty.

\section{Wyniki sondowań statycznych (CPT/ (PTU) i sondowań dylatometrycznych (DMT)}

Wybrane wyniki badań uzyskane w profilu badawczym od strony wody górnej (WG) w hektometrze (hm) 4+50 przed obciążeniem i pod koniec 1 etapu (5,5 miesiąca od rozpoczęcia budowy) w postaci profili pomierzonych wartości sondowań statycznych gruntu: oporu stożka $\mathrm{q}_{\mathrm{c}}$, tarcia na tulei $\mathrm{f}_{\mathrm{s}}$ oraz współczynnika tarcia $\mathrm{R}_{\mathrm{f}}$ przedstawiono na rycinie 3 . Porównanie wartości uzyskanych oporów stożka w profilach badawczych wykonanych poza strefą obciążoną porównano $\mathrm{z}$ wartościami otrzymanymi $\mathrm{w}$ profilach

Tabela 2. Właściwości fizyczne gruntów organicznych w Nieliszu (Rabarijoely 2000, Lechowicz i in. 2004)

Table 2. Index properties of organic soils at the Nielisz test sites (Rabarijoely 2000, Lechowicz i in. 2004)

\begin{tabular}{|c|c|c|c|c|c|c|c|}
\hline \multirow[b]{2}{*}{$\begin{array}{l}\text { Obiekt } \\
\text { Site }\end{array}$} & \multirow[b]{2}{*}{$\begin{array}{l}\text { Rodzaj gruntu } \\
\text { Soil type }\end{array}$} & \multirow[b]{2}{*}{$\begin{array}{c}\text { Zawartość części } \\
\text { organicznych } \\
\text { Organic content } \\
\qquad \mathrm{I}_{\mathrm{om}}\end{array}$} & \multirow[b]{2}{*}{$\begin{array}{l}\text { Zawartość } \\
\text { Content } \\
\mathrm{CaCO}_{3}\end{array}$} & \multirow[b]{2}{*}{$\begin{array}{c}\text { Wilgotność } \\
\text { Water content } \\
\mathrm{W}_{\mathrm{n}}\end{array}$} & \multirow[b]{2}{*}{$\begin{array}{c}\text { Granica } \\
\text { płynności } \\
\text { Liquid limit } \\
\mathrm{w}_{\mathrm{L}}\end{array}$} & \multicolumn{2}{|c|}{ Gęstość /Density } \\
\hline & & & & & & $\begin{array}{c}\text { Objętościowa } \\
\text { Unit weight of } \\
\text { soil } \\
\rho \\
\end{array}$ & $\begin{array}{c}\text { Właściwa } \\
\text { Specific we- } \\
\text { ight of soil } \\
\rho_{\mathrm{s}}\end{array}$ \\
\hline \multirow{3}{*}{ Nielisz } & Namuł & \multicolumn{4}{|c|}{$[\%]$} & \multicolumn{2}{|c|}{$\left[\mathrm{t} \mathrm{m}^{-3}\right]$} \\
\hline & $\begin{array}{l}\text { Organic mud } \\
\left(\mathrm{M}_{\mathrm{or}}\right)\end{array}$ & $20-30$ & - & $120-150$ & $130-150$ & $1.25-1.30$ & $2.25-2.3$ \\
\hline & $\begin{array}{l}\text { Namuł } \\
\text { organiczny/ } \\
\text { Organic mud } \\
\left(\mathrm{M}_{\mathrm{or}}\right)\end{array}$ & $10-20$ & - & $105-120$ & $110-130$ & $1.30-1.45$ & $2.30-2.40$ \\
\hline
\end{tabular}



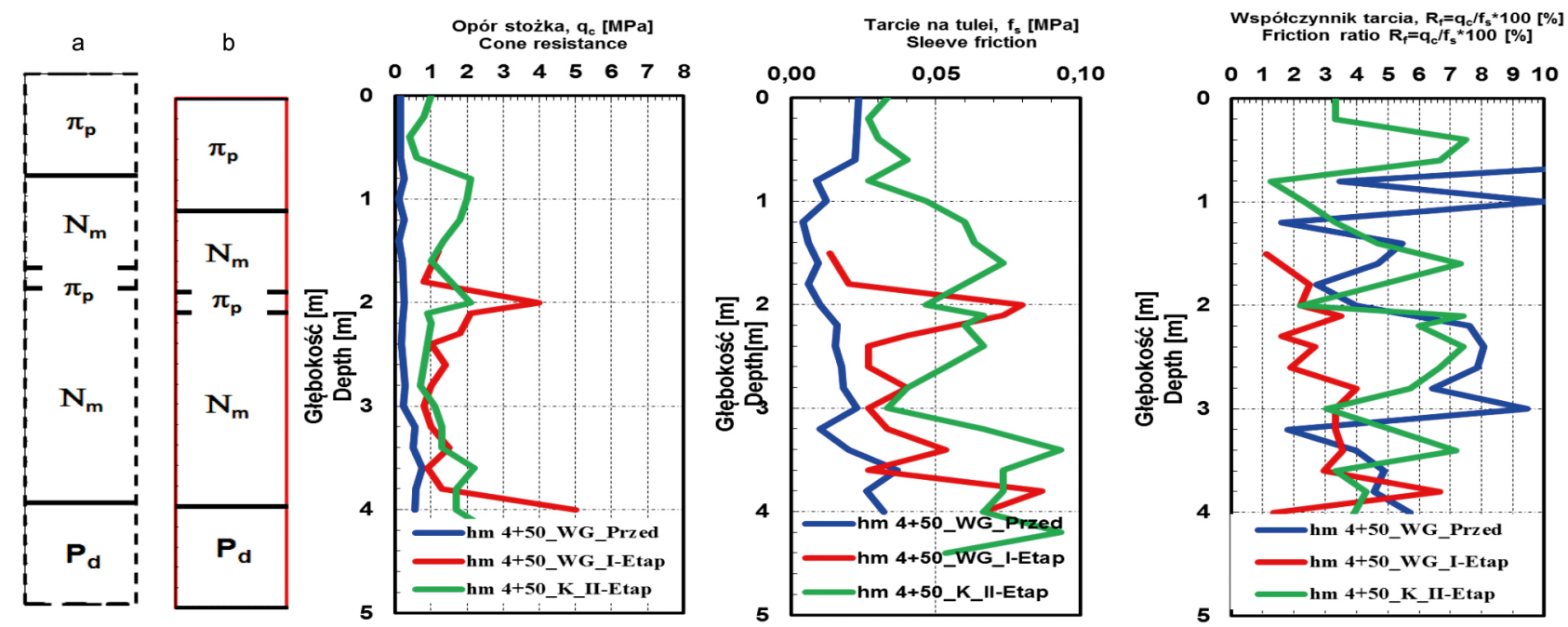

Ryc. 3. Profile qc, fs i Rf uzyskane z badań sonda statycznych CPT dla podłoża słabonośnego zapory Nielisz: a - profil podłoża nieobciążonego; $\mathrm{b}$ - profil podłoża obciążonego; $\pi$ p - pył piaszczysty, Nm - namuł organiczny, $\pi$ - pył, Pd - piasek drobny, hm - hektometr, WG - woda górna, WD - woda dolna, K - korona

Fig. 3. Profile qc, fs and Rf obtained from CPT tests at the Nielisz site: a - natural subsoil; b - under loading; $\pi \mathrm{p}$ - sandy silt, $\mathrm{Nm}$ - organic mud, $\pi$ - clay, Pd - fine sand, hm - hectometer, WG - upstream WD - downstream, K - crown

wykonanych pod nasypem przeciążeniowym wykazuje istotne zmiany wywołane procesem konsolidacji.

Skutkiem wzrostu naprężenia efektywnego ponad początkową wartość naprężenia prekonsolidacji jest zwiększenie oporu stożka do wartości około 1,2 MPa oraz zmniejszenie współczynnika tarcia $\mathrm{R}_{\mathrm{f}}$. Wyniki badań dylatometrycznych dla tego samego profilu badawczego przedstawione w postaci profili pomierzonych wartości oraz wartości średnich wraz z odchyleniem standardowym dylatometrycznych wskaźników gruntu (wskaźnika materiałowego $\mathrm{I}_{\mathrm{D}}$, wskaźnika naprężenia poziomego $\mathrm{K}_{\mathrm{D}}$ i modułu dylatometryczne- go $E_{D}$ oraz wskaźnika ciśnienia wody w porach $U_{D}$ ) przedstawiono na rycinie 4. Wartości wskaźników dylatometrycznych uzyskanych w profilach badawczych wykonanych poza strefą obciążoną porównane z wartościami otrzymanymi w profilach wykonanych pod nasypem przeciążeniowym wykazują również na istotne zmiany wywołane procesem konsolidacji. Skutkiem wzrostu naprężenia efektywnego ponad początkową wartość naprężenia prekonsolidacji jest zmniejszenie wskaźnika naprężenia poziomego $\mathrm{K}_{\mathrm{D}}$ do wartości około 2,0 wskazującej stan normalnie konsolidowany i zwiększenie wskaźnika materiałowego $\mathrm{I}_{\mathrm{D}}$.
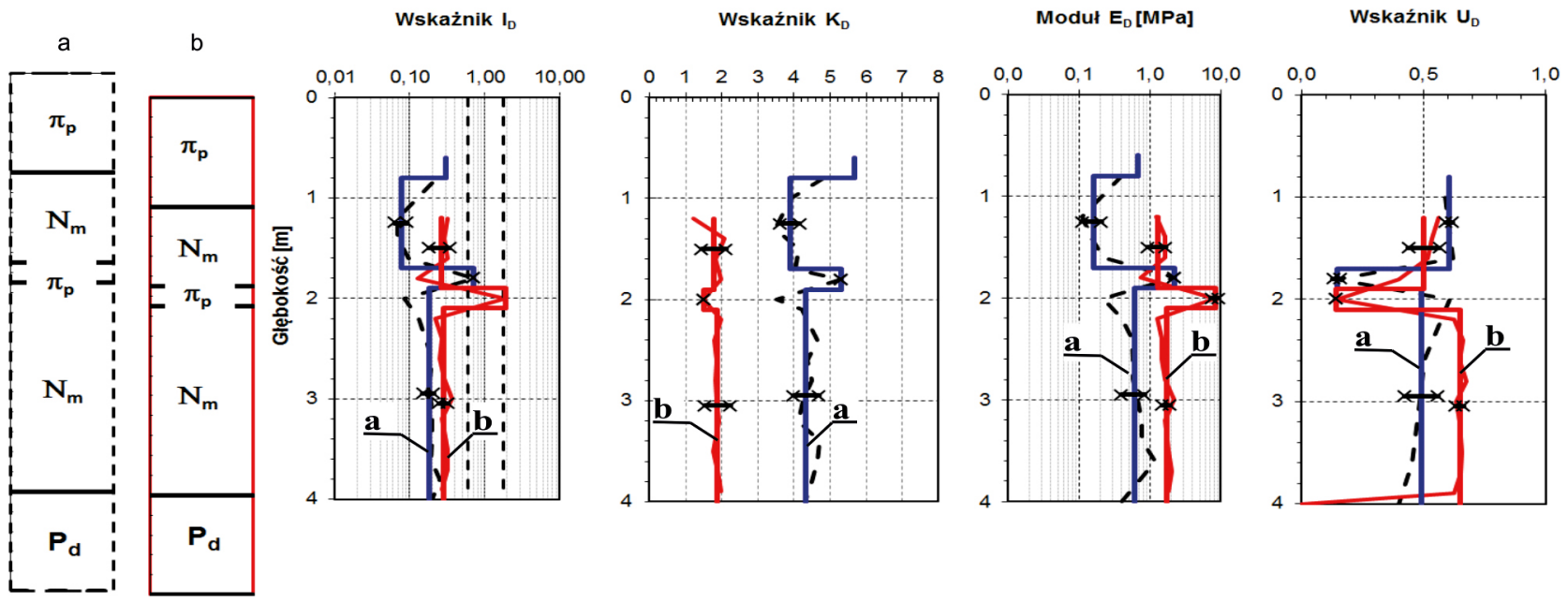

Ryc. 4. Wskaźniki dylatometryczne (ID, KD, ED i UD) uzyskane z badań DMT dla podłoża słabonośnego zapory Nielisz: $\mathrm{a}$ - profil podłoża nieobciążonego; $\mathrm{b}$ - profil podłoża obciążonego; $\pi$ p - pył piaszczysty, Nm - namuł organiczny, $\pi$ - pył, Pd - piasek drobny

Fig. 4. Index parameters ID, KD, ED and UD profiles from dilatometer test at the Nielisz site: $a$ - natural subsoil; $b$ - under loading a - natural subsoil; b - under loading; $\pi \mathrm{p}$ - sandy silt, $\mathrm{Nm}$ - organic mud, $\pi$ - clay, Pd - fine sand 


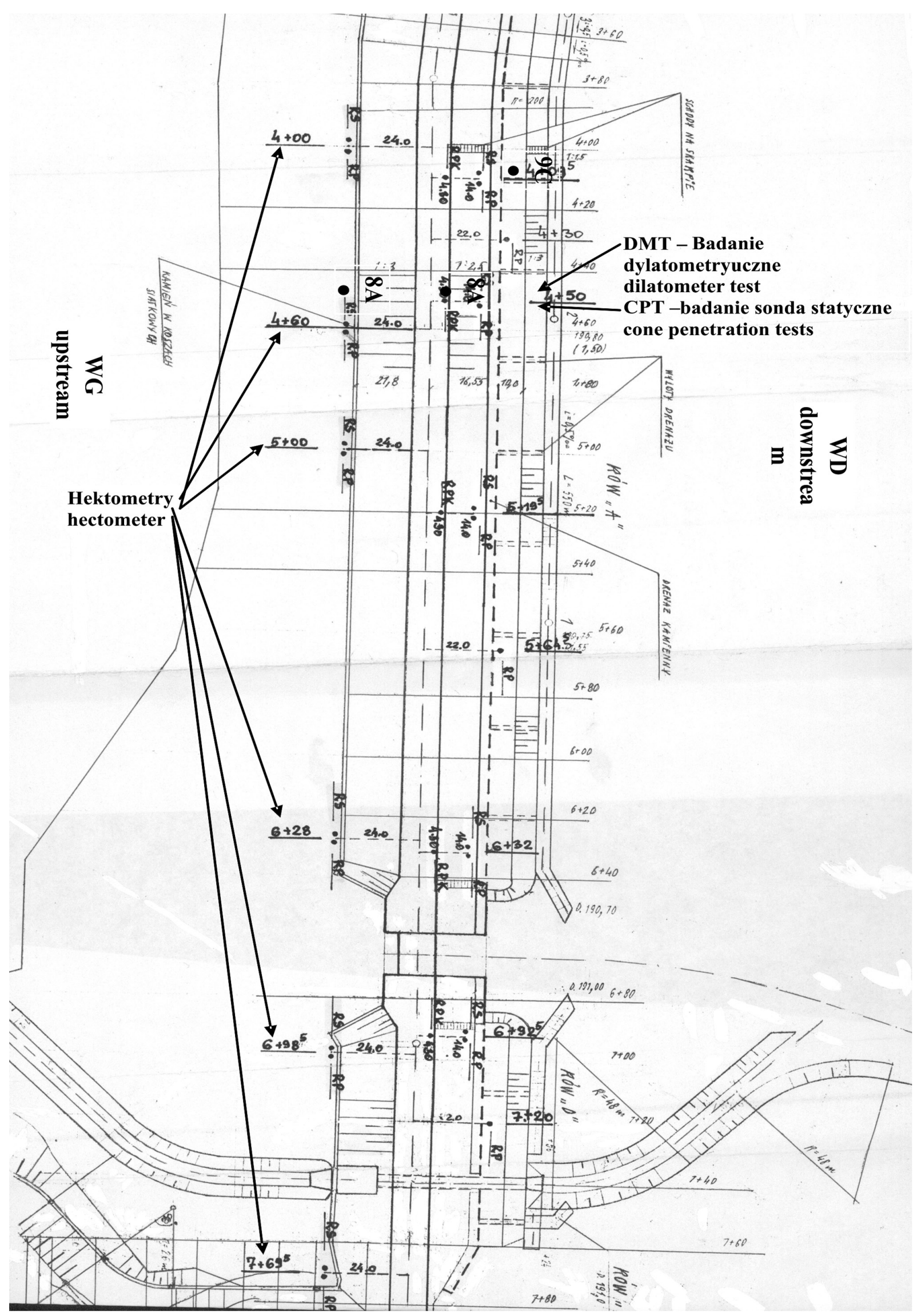

Ryc. 5. Lokalizacja sondowań CPT i DMT wykonanych na rejonie zapory czołowej w Nieliszu Fig. 5. CPT and DMT location soundings performed at the Nielisz site 
Tabela 3. Wartości modułu ściśliwości M [MPa] dla gruntów z badań CPT i DMT na zaporze wodnej w Nieliszu Table 3. Values of constrained modulus M [MPa] sediments based on CPT and DMT tests from the Nielisz dam

\begin{tabular}{ccccc}
\hline $\begin{array}{c}\text { Rok } \\
\text { Year }\end{array}$ & $\begin{array}{c}\text { Wartość średnia } \\
\text { Mean values }\end{array}$ & $\begin{array}{c}\text { Odchylenie standardowe } \\
\text { Standard deviation }\end{array}$ & $\begin{array}{c}\text { Zakres } \\
\text { Range }\end{array}$ & $\begin{array}{c}\text { Przedział ufności } \\
\text { Confidence interval }\end{array}$ \\
\hline \multicolumn{5}{c}{ warstwa pyłu piaszczystego - sandy silt layer } \\
\hline 1994 & 3,19 & 3,11 & $0,08-6,30$ & $1,95-4,43$ \\
$1995-1996$ & 11,17 & 11,06 & $0,11-22,83$ & $7,28-15,06$ \\
\hline \multicolumn{5}{c}{ warstwa namułu górnego - upper organic mud layer } \\
\hline 1994 & 3,39 & 2,72 & $0,66-6,11$ & $2,46-4,32$ \\
$1995-1996$ & 4,43 & 3,47 & $0,96-7,90$ & $2,91-5,94$ \\
\hline 1994 & 10,15 & warstwa pyłu - silt layer \\
\hline $1995-1996$ & 11,39 & 9,72 & $0,43-19,87$ \\
\hline 1994 & warstwa namułu dolnego - lower organic mud layer & $4,13-16,18$ \\
$1995-1996$ & 3,55 & 3,29 & $0,26-6,84$ \\
\end{tabular}

W wyniku konsolidacji podłoża organicznego moduł dylatometryczny $\mathrm{E}_{\mathrm{D}}$ uległ kilkukrotnemu zwiększeniu. W procesie konsolidacji zaobserwowano zwiększenie wartości wskaźnika ciśnienia wody w porach $\mathrm{U}_{\mathrm{D}} \mathrm{W}$ warstwie dolnego namułu organicznego.

Pierwszym krokiem do analizy statystycznej było uzyskanie wartości pomierzonych za pomocą sondowań CPT i DMT lub badań laboratoryjnych oraz obserwacji geodezyjnych. Wyniki otrzymane w roku 1994 przedstawiają parametry podłoża pod nasypem obciążającym. W roku 1995 i 1996 powtórnie wykonano badania sondą CPT i DMT po zdjęciu nasypu obciążającego. W artykule analizowane były wybrane trzy miejsca badań: WD (woda dolna): punkt 9C w hm $4+10$, K (korona), punkt 8A oraz WG (woda górna): punkt $8 \mathrm{~B} \mathrm{w} \mathrm{hm} 4+50$. Położenie tych punktów przedstawiono na mapie (ryc. 5).

Na podstawie wygenerowanych wartości średnich oraz odchyleń standardowych dla poszczególnych warstw wyliczono wartość typową badanego parametru $\mathrm{x}_{\text {typ }}$. Tabela 3 przedstawia wyniki uzyskane $z$ analizy klasycznej dla badań CPT oraz DMT zapory czołowej w Nieliszu. Do obliczeń wykorzystano parametr geotechniczny - modułu ściśliwości M. Dla tego parametru wydzielono między innymi obszar zmienności oraz przedział ufności. Na rycinie 6 przedstawiono wykresy wygenerowane za pomocą programu BAYANAL. Prezentują one zależność badanego parametru M od gęstości prawdopodobieństwa.

W celu wprowadzenia danych do programu Surfer $10.0 \mathrm{w}$ tabelach 4 i 5 zestawiono średnie warto-

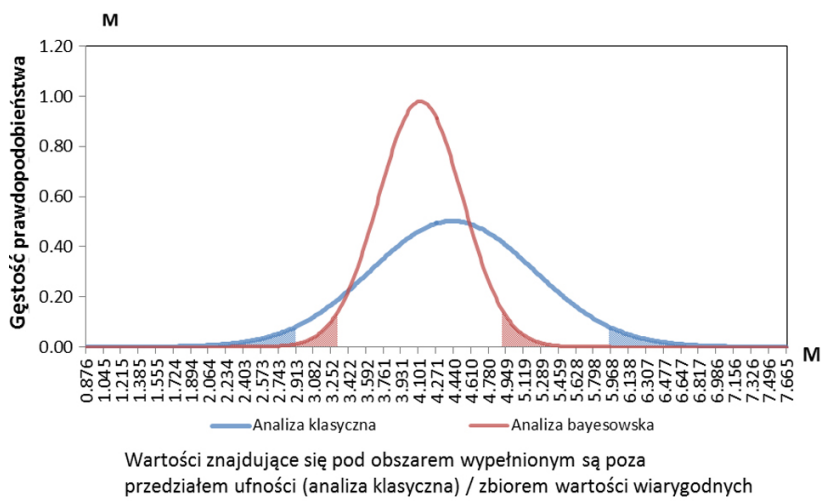

Ryc. 6. Gęstość prawdopodobieństwa badanego parametru $\mathrm{M}$ wykonanych w rejonie zapory czołowej w Nieliszu Fig. 6. Dependence of the tested parameter M of probability density performed on the region of the Nielisz dam

Tabela 4. Średnie wartości modułu ściśliwości M dla warstw wyznaczonych w oparciu o badania CPT i DMT na zaporze czołowej w Nieliszu (badania z roku 1994)

Table 4. Average values of constrained modulus for layers designated based on CPT and DMT tests at the Nielisz dam (measurements from 1994)

\begin{tabular}{|c|c|c|c|c|c|c|}
\hline \multirow[t]{2}{*}{$\begin{array}{c}\text { Warstwa } \\
\text { Layer }\end{array}$} & $\begin{array}{c}\text { Głębokość } \\
\text { Depth }\end{array}$ & $\begin{array}{c}\mathrm{M} \\
94 \_8 \mathrm{~A} \\
(\mathrm{hm} 4+50, \mathrm{WG})\end{array}$ & $\begin{array}{c}\text { Głębokość } \\
\text { Depth }\end{array}$ & $\begin{array}{c}\mathrm{M} \\
94-9 \mathrm{C} \\
(\mathrm{hm} 4+10, \mathrm{WD})\end{array}$ & $\begin{array}{c}\text { Głębokość } \\
\text { Depth }\end{array}$ & $\begin{array}{c}\mathrm{M} \\
9488 \mathrm{~B} \\
(\mathrm{hm} 4+50, \mathrm{~K})\end{array}$ \\
\hline & {$[\mathrm{m}]$} & {$[\mathrm{MPa}]$} & {$[\mathrm{m}]$} & {$[\mathrm{MPa}]$} & {$[\mathrm{m}]$} & {$[\mathrm{MPa}]$} \\
\hline Pył piaszczysty/Sandy silt & $0,6-0,8$ & 1,02 & $0,9-2,0$ & 1,15 & $3,5-5,4$ & 10,85 \\
\hline $\begin{array}{l}\text { Namuł górny/Upper organic } \\
\text { mud layer }\end{array}$ & $0,9-1,6$ & 0,46 & $2,1-3,1$ & 4,10 & $5,5-6,8$ & 4,51 \\
\hline Pył/Silt & $1,7-1,9$ & 2,97 & $3,2-3,5$ & 12,47 & $6,9-7,2$ & 11,43 \\
\hline $\begin{array}{l}\text { Namuł dolny/Lower organic } \\
\text { mud layer }\end{array}$ & $2,0-3,9$ & 0,89 & $3,6-5,5$ & 5,37 & $7,3-8,0$ & 8,29 \\
\hline
\end{tabular}


Tabela 5. Średnie wartości modułu ściśliwości M dla warstw wyznaczonych w oparciu o badania CPT i DMT na zaporze czołowej w Nieliszu (badania z lat 1995-1996)

Table 5. Average values of constrained modulus M for layers designated based on CPT and DMT tests at the Nielisz dam (measurements from 1995-1996)

\begin{tabular}{|c|c|c|c|c|c|c|}
\hline \multirow[t]{2}{*}{$\begin{array}{c}\text { Warstwa } \\
\text { Layer }\end{array}$} & $\begin{array}{l}\text { Głębokość } \\
\text { Depth }\end{array}$ & $\begin{array}{c}\mathrm{M} \\
95 \_8 \mathrm{~A} \\
(\mathrm{hm} 4+50, \mathrm{WG})\end{array}$ & $\begin{array}{l}\text { Głębokość } \\
\text { Depth }\end{array}$ & $\begin{array}{c}\mathrm{M} \\
96-9 \mathrm{C} \\
(\mathrm{hm} \mathrm{4+10,WD})\end{array}$ & $\begin{array}{c}\text { Głębokość } \\
\text { Depth }\end{array}$ & $\begin{array}{c}\mathrm{M} \\
95 \_8 \mathrm{~B} \\
(\mathrm{hm} \mathrm{4+50,K)}\end{array}$ \\
\hline & {$[\mathrm{m}]$} & {$[\mathrm{MPa}]$} & {$[\mathrm{m}]$} & {$[\mathrm{MPa}]$} & {$[\mathrm{m}]$} & {$[\mathrm{MPa}]$} \\
\hline Pył piaszczysty/Sandy silt & $3,6-4,6$ & 8,50 & $3,4-3,7$ & 13,11 & $6,6-8,4$ & 12,14 \\
\hline $\begin{array}{l}\text { Namuł górny/Upper organic } \\
\text { mud layer }\end{array}$ & $4,7-5,3$ & 3,50 & $3,8-5,1$ & 5,74 & $8,5-8,8$ & 6,33 \\
\hline Pył/Silt & $5,4-5,6$ & 14,70 & $5,2-5,7$ & 7,92 & $8,9-9,1$ & 15,01 \\
\hline $\begin{array}{l}\text { Namuł dolny/Lower organic } \\
\text { mud layer }\end{array}$ & $5,7-7,3$ & 2,51 & $5,8-7,0$ & 4,00 & $9,2-10,1$ & 6,53 \\
\hline
\end{tabular}

ści parametru M dla poszczególnych warstw wyznaczonych za pomocą badań polowych. Ryciny 9 i 10 przedstawiają mapy izolinii wygenerowane przez program Surfer 10.0. Dodatkowo dzięki zastosowanemu oprogramowaniu możliwe jest przedstawienie widoku podłoża gruntowego w wersji 3D (ryc. 8).

Wariogramy empiryczne sporządzone dla wartości modułu ściśliwości M namułu górnego i dolnego, odznaczały się nieregularnym przebiegiem (ryc. 7 i 8), który spowodował znaczne trudności w znalezieniu funkcji teoretycznych, umożliwiających dokładną ich aproksymację. Nieregularny przebieg wariogramów empirycznych wynikał z małej liczby punktów pomiarowych wykorzystanych do ich konstrukcji. Należy jednak podkreślić, że każdy z punktów po-

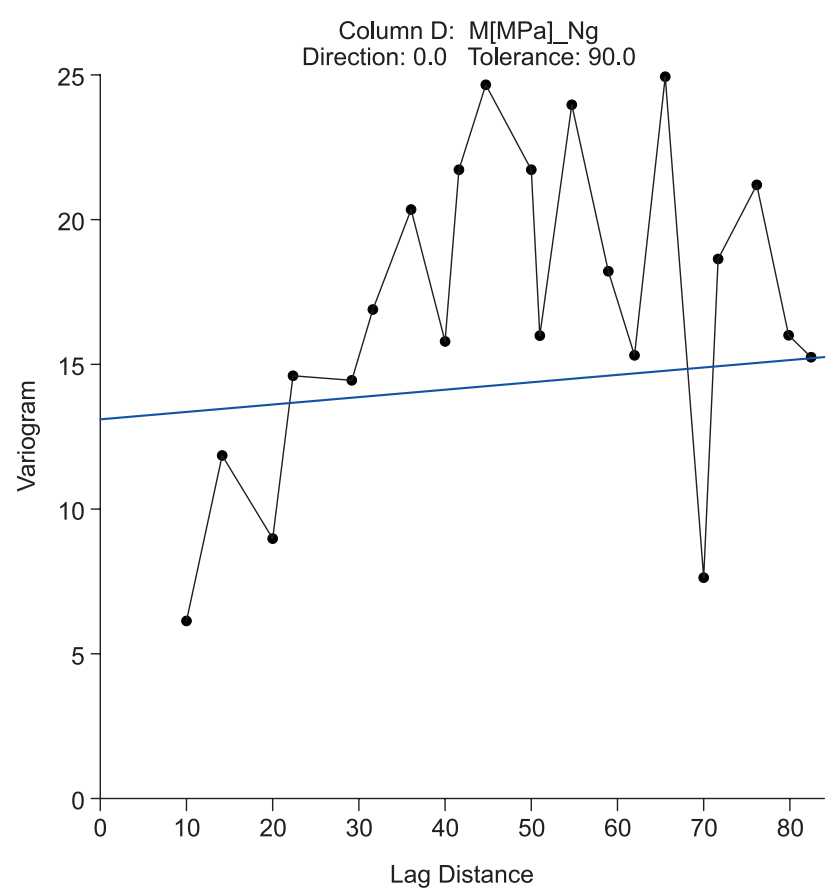

Ryc. 7. Wariogramy empiryczny oraz teoretyczny dla modułu ścisliwości wartwy namułu górnego

Fig. 7. Empirical and theoretical variograms for the constrained modulus for upper organic mud miarowych stanowił reper powierzchniowy i wgłębny. Pomimo, że na potrzeby interpolacji wartości modułu ściśliwości M dla namułu górnego i dolnego, liczba punktów pomiarowych wynosiła tylko 14 , to biorąc pod uwagę wymogi monitoringu obiektu w budownictwie hydrotechnicznym, liczba reperów umożliwiła stworzenie spójnej sieci pomiarowej. Autor wykorzystał do konstrukcji wariogramów wszystkie dostępne punkty pomiarowe zlokalizowane w obrębie zapory wodnej w Nieliszu.

W związku ze znacznymi trudnościami w znalezieniu funkcji teoretycznych do aproksymacji sporządzonych wariogramów podjęto arbitralną decyzję o zastosowaniu w tym celu funkcji liniowej, o nachyleniu w zakresie $(0,001 ; 0,1)$ oraz funkcji wykładniczej:

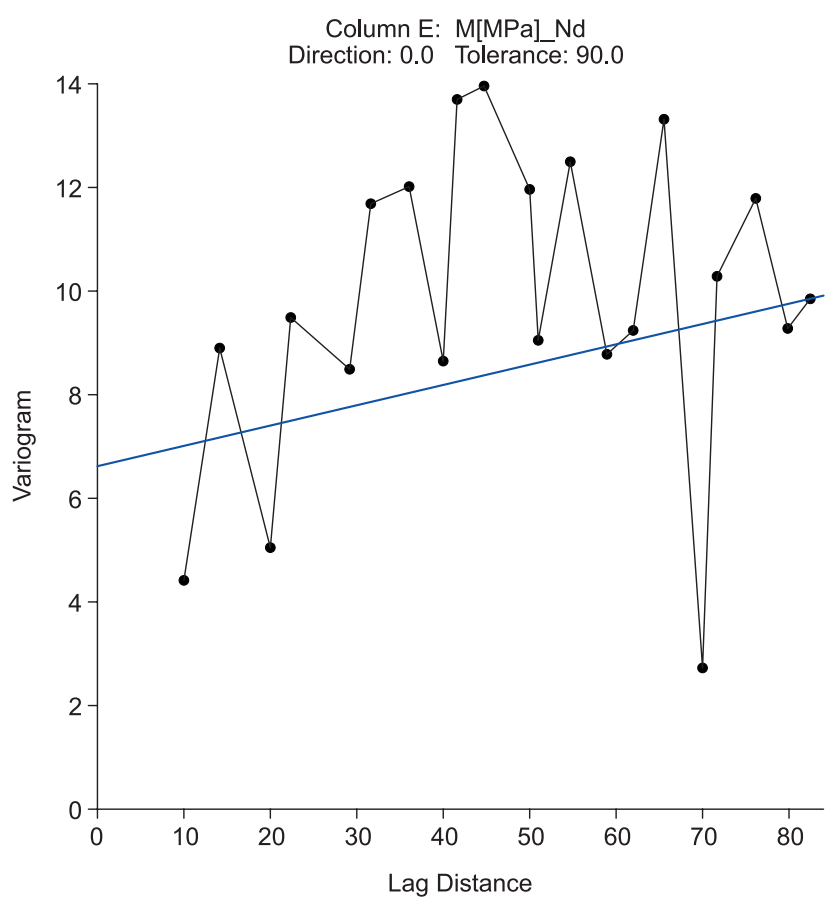

Ryc. 8. Wariogramy empiryczny oraz teoretyczny dla modułu ścisliwości wartwy namułu dolnego

Fig. 8. Empirical and theoretical variograms for the constrained modulus for lower organic mud 


$$
\gamma(\mathrm{h})=\mathrm{C}\left(1-\mathrm{e}^{-\mathrm{h}}\right)
$$

i funkcji potęgowej:

$$
\gamma(\mathrm{h})=\mathrm{C}\left(\mathrm{e}^{\mathrm{n}}\right)
$$

gdzie:

$C$ - wartość progowa,

$n$ - wykładnik funkcji potęgowej,

$h$ - względny dystans pomiędzy punktami dobieranymi $\mathrm{w}$ pary podczas tworzenia wariogramu, stanowiący iloraz odległości pomiędzy tymi punktami i zasięgu oddziaływania

$$
\mathrm{h}=\frac{\sqrt{\Delta \mathrm{x}^{2}+\Delta \mathrm{y}^{2}}}{\mathrm{~A}}
$$

$A$ - zasięg oddziaływania.

W kolejnym kroku wykonano interpolację wartości modułu ściśliwości $M$ dla rozpatrywanych hektometrów z wykorzystaniem wyżej wymienionych funkcji, jako arbitralnie wybranych wariogramów teoretycznych, oraz porównano uzyskane $\mathrm{w}$ ten sposób mapy izolinii modułu ściśliwości M (ryc. 7 i 8). Nie stwierdzono istotnych różnic pomiędzy wartościami interpolowanymi, które uzyskano dla każdego z rozpatrywanych etapów w wyniku przyjęcia równań funkcji linowej o nachyleniach dobieranych $z$ wyżej wymienionego przedziału. Różnice pomiędzy wartościami modułu ściśliwości M interpolowanymi przy zastosowaniu funkcji liniowej a wartościami modułu ściśliwości $\mathrm{M}$ interpolowanymi przy zastosowaniu funkcji wykładniczej są również niewielkie.

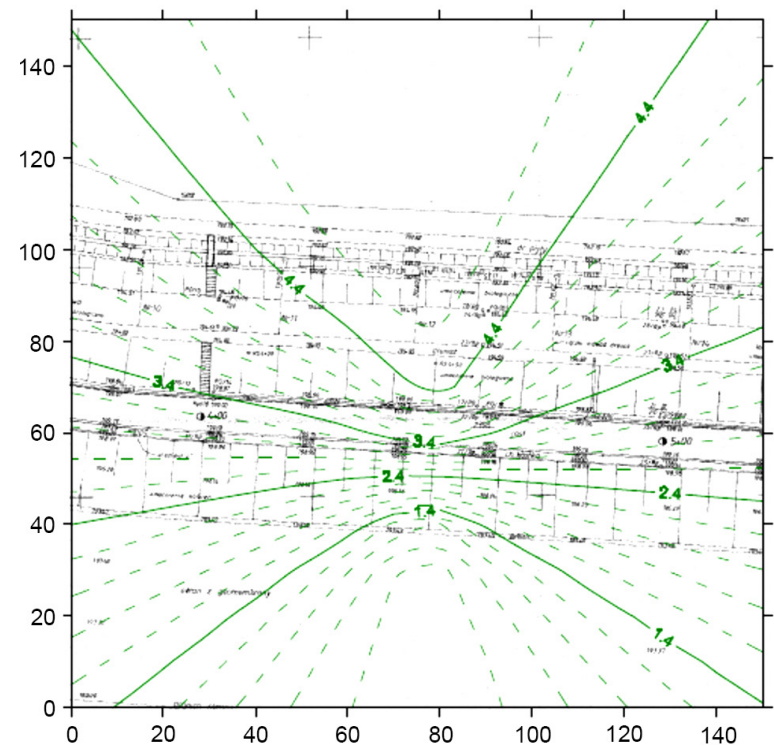

Ryc. 9. Izolinie modułu ściśliwości $\mathrm{M}[\mathrm{MPa}]$ dla namułu górnego w oparciu o badania z lat 1995 i 1996

Fig. 9. Isolines of constrained modulus $\mathrm{M}$ [MPa] for mud layer based on research from the years 1995 and 1996

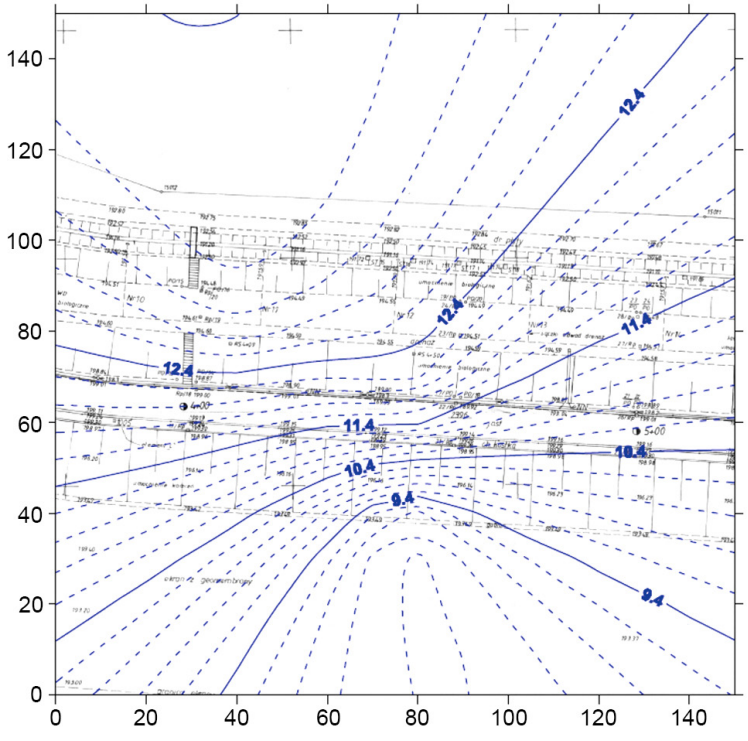

Ryc. 10. Izolinie modułu ściśliwości M [MPa] dla warstwy pyłu w oparciu o badania $z$ lat 1995 i 1996

Fig. 10. Isolines of constrained modulus $\mathrm{M}[\mathrm{MPa}]$ for silt layer based on research from the years 1995 and 1996

\section{Interpretacja uzyskanych wyników}

Analizując wyniki uzyskane za pomocą wnioskowania klasycznego oraz metody interpolacji krigingu można stwierdzić, że parametry gruntowe po zastosowaniu nasypu obciążającego uległy dużej zmianie. Jak widać na wyżej zamieszczonych rycinach oraz tabelkach moduł ściśliwości M dla badań polowych przeprowadzonych w latach 1995 i 1996 są o około 6,50 MPa większe niż dla badań z roku 1994.

Parametrem podanym interpolacji krigingu był moduł ściśliwości $M$. Jego najmniejsza wartość dla pyłu piaszczystego wyniosła 8,6 MPa w okolicy wody górnej, zaś największa 13,2 MPa w miejscu wody dolnej. W przypadku namułu górnego wartości $M$ wahają się w granicach od 3,6 do 6,4 MPa. Największa wartość modułu ścinania $\mathrm{M}$ dla pyłu obliczona została dla punktu znajdującego się na skarpie zapory od stron wody górnej, zaś najmniejsza na przeciwległej stronie skarpy. Mapa izolinii dla namułu dolnego przedstawia zakres modułu od wartości 2,4 MPa do 6,2 $\mathrm{MPa}$.

W podsumowaniu artkułu przedstawiono widok 3D podłoża gruntowego (ryc. 11). Na jego podstawie można stwierdzić, że warstwa pyłu piaszczystego zmniejsza swoją miąższość w kierunku od wody dolnej do wody górnej. Stwierdzono także, że miąższość warstwy namułu górnego waha się $\mathrm{w}$ granicach od 2 do 0,5 m. Między nimi występuje cienka warstwa pyłu. Najniżej zalegający namuł występuje po stronie wody dolnej, jednak większa (około $2 \mathrm{~m}$ ) miąższość tego gruntu znajduję się pod poziomem wody górnej. Pod ostatnią badaną warstwą namułu zalegają piaski. 


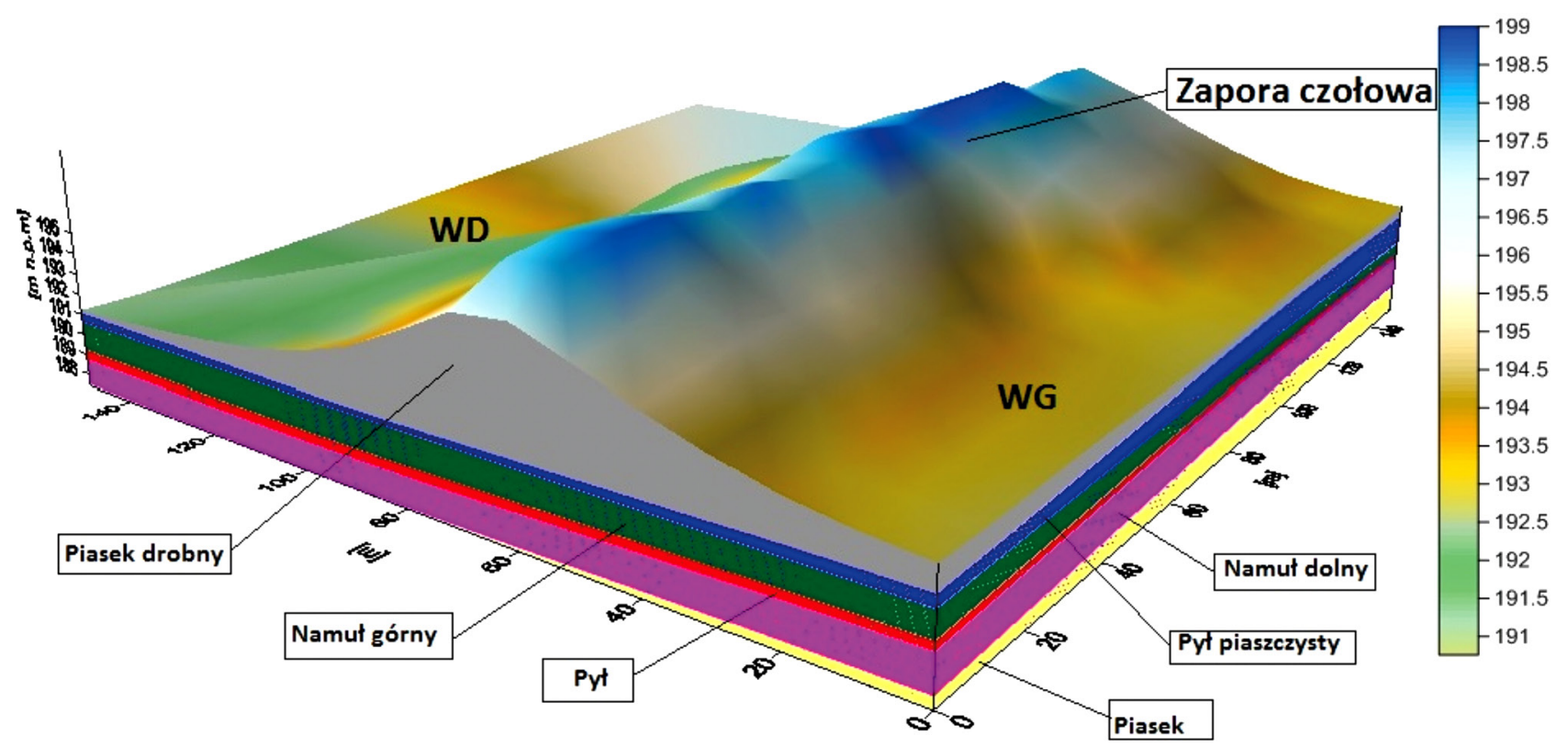

Ryc. 11. Widok 3D podłoża gruntowego pod zaporą czołową w Nieliszu (opracowane na podstawie badań CPT i DMT z lat 1995-1996)

Fig. 11. The 3D view of the organic subsoil of the Nielisz dam (developed on the basis of CPT, DMT tests and geodesic observation from the years 1995-1996)

\section{Podsumowanie i wnioski}

Niniejszy artykuł skupia się na problemie doboru parametrów w projektowaniu budowli geotechnicznych $z$ wykorzystaniem metod statystycznych. Wśród tych metod możemy wymienić analizę statystyczną klasyczną czy też coraz częściej używaną w geotechnice metodę geostatystyczną. Spośród wielu metod estymacji użytych $\mathrm{w}$ geostatystyce warto zwrócić uwagę na technikę krigingu. Zaletą tej metody interpolacji, bazującej na analizie semiwariogramów, jest możliwość przedstawienia zmienności przestrzennej konkretnego parametru geotechnicznego. Ponadto, jak wynika $\mathrm{z}$ badań przedstawionych $\mathrm{w}$ artykule, zmienność modułu ściśliwości dla metody krigingu jest węższa, co wpływa na podniesienie dokładności tej metody.

Do analizy statystycznej w artykule wykorzystano wyniki uzyskane $z$ badań terenowych sondą statyczną CPT oraz z badań dylatometrycznych DMT. Na początku artykułu krótko opisane zostały parametry podlegające analizie statystycznej. Dodatkowo w części teoretycznej artykułu przedstawiono metodykę badań oraz sposób interpretacji wyników pomiarowych uzyskanych z badań CPT oraz DMT. W formie tabeli przedstawiono zaś korelacje empiryczne, na podstawie których wyliczone zostały parametry geotechniczne.

\section{Literatura}

Bipromel, 1994. Zbiornik wodny Nielisz - zapora czołowa. Projekt techniczny, Warszawa.

Bipromel, 1997. Dokumentacja geologiczna piezometrów otwartych wykonanych w korpusie zapory czołowej zbiornika Nielisz.

Bortkiewicz A., Szmagaj J., 1996. Zbiornik Nielisz - charakterystyka konstrukcyjna obiektów zapory czołowej. Przegląd Naukowy Wydziału Melioracji i Inżynierii Środowiska 12: 291-302.

Cressie N., 1991. Statistics for Spatial Data. John Wiley and Sons, New York.

Garbulewski K., Jabłonowski S., RabarijoelyS., 2007. Zastosowanie analizy bayesowskiej w projektowaniu geotechnicznym. Inżynieria Morska i Geotechnika 3: 163-169.

Geoproblem, 1992. Dokumentacja geologiczno - inżynierska do PT budowy zapory ziemnej stopnia Nielisz w Nieliszu. Etap II. Zamość.

Geoteko, 1992. Opracowanie technologii etapowego wykonania zapory Nielisz z wykorzystaniem konsolidacyjnego wzmocnienia podłoża. Wesoła $\mathrm{k} /$ Warszawy.

Geoteko, 1994. Badania geotechniczne w celu określenia warunków umożliwiających przyspieszenie realizacji zapory czołowej zbiornika wodnego Nielisz. Wesoła k/Warszawy.

Geoteko, 1995. Okresowe badania geotechniczne przed rozpoczęciem II etapu budowy zapory czołowej zbiornika wodnego Nielisz. Wesoła k/Warszawy.

Katedra Geotechniki, 1989. Budowa nasypów na gruntach organicznych - materiały pomocnicze do projektowania, wykonawstwa i utrzymania nasypów na gruntach organicznych. SGGW, Warszawa.

Kokesz Z., 2010. Korzyści sporządzania map izoliniowych procedurą krigingu zwyczajnego. Górnictwo Odkrywkowe 51(2): 91-95.

Lechowicz Z., Rabarijoely S., Szczypiński P., 2004. Wykorzystanie badań dylatometrycznych do określania rodzaju gruntów organicznych. Przegląd Naukowy Wydziału Melioracji i Inżynierii Środowiska XIII(2/29): 191-201.

Lunne T., Robertson P.K., Powell J., 1997. Cone penetration testing in geotechnical practice. E \& FN Spon, London. 
Marchetti S., 1980. In Situ Tests by Flat Dilatometer. Journal of the Geotechnical Engineering Division, ASCE 106(GT3): 299-321.

Marmol U., 2002. Modelowanie reprezentacji powierzchni topograficznej $z$ wykorzystaniem metody geostatystycznej. 8(2): 269-270.

Meigh A.C., 1987. Cone Penetration Testing Methods and Interpretation. CIRIA Ground Engineering Report; In-Situ Testing.

Młynarek Zb., Tschuschke W., Gogolik S., Grajek E., 2003. Wykorzystanie sondowań statycznych i badań dylatometrycznych do oceny zmienności cech fizycznych osadów poflotacyjnych wbudowanych w zapory składowiska Żelazny Most. Inzynieria Morska i Geotechnika 2: 93-96.

Rabarijoely S., 2000. Wykorzystanie badań dylatometrycznych do wyznaczania parametrów gruntów organicznych obciążeniem nasypem. MS PhD thesis, SGGW, Warszawa.

Rabarijoely S., 2012. Obliczenia stateczności zapory w Nieliszu w odniesieniu do Eurokodu 7. Scientiarum Polonorum ACTA, Architectura 11(1): 15-28.

Rabarijoely S., Garbulewski K., Jabłonowski S., 2012. Dobór parametrów wytrzymałościowo-odkształceniowych gruntów spoistych $\mathrm{w}$ projektowaniu geotechnicznym według Eurokodu $7 \mathrm{z}$ wykorzystaniem analizy bayesowskiej. Raport projektu N N506 432436 .
Rabarijoely S., Jabłonowski S., Garbulewski K., 2013. Dobór parametrów geotechnicznych $\mathrm{z}$ wykorzystaniem teorii Bayesa. Budownictwo i Inżynieria Środowiska 4(3): 211-218.

Schmertmann J.H., 1986. Dilatometer to Compute Foundation Settlement. Proc. In Situ '86 ASCE Spec. Conf. Virginia Tech, Blacksburg, VA, June 1986. ASCE Geot. Special Publ. 6: 303321.

Schmertmann J.H., 1988. Guidelines for Using the CPT, CPTU and Marchetti DMT for Geotechnical Design. U.S. Department of Transportation, Federal Highway Administration, Office of Research and Special Studies, Report No. FHWA-PA 87-023+24, Vol. 3-4.

Smith M.G., Houlsby G.T., 1995. Interpretation of the Marchetti Dilatometer in Clay. 11th European Conference on Soil Mechanics and Foundation Engineering 1, Copenhagen.

Spółka Wodno-Ściekowa Wieprz, 1991. Zbiornik wodny Nielisz na rzece Wieprz, stopień czołowy - zapora ziemna $z$ fartuchem. Projekt techniczny jednostadiowy, Zamość.

Zawadzki J., 2011. Metody geostatystyczne dla kierunków przyrodniczych i technicznych. Warszawa. Oficyna Wydawnicza Politechniki Warszawskiej, Warszawa. 